\title{
Порушення агрегації тромбоцитів як чинник розвитку Аіवбетичної макулопатії та Аіабетичного макулярного набряку у хворих на непроліферативну Аіабетичну ретинопатію при цукровому Аїбеті 2-го типу
}

\begin{abstract}
Резюме. Актуальність. Аналіз сучасних даних дає можливість висунути припущення, що патогенетичні чинники иукрового діабету (ЦД) можуть провокувати проагрегантний статус тромбоцитів (Ти) та викликати порушення мікроциркуляції в оболонках ока і розвиток діабетичної макулопатії (ДМП) та діабетичного макулярного набряку (ДМН). Мета дослідження - проаналізувати порушення агрегації Ти, при ДМН та ДМПза умов непроліферативної діабетичної ретинопатії (НПДР) при ЦД 2-го типу. Матеріали та методи. Дослідження включало 32 хворих (32 ока) із ЦД 2-го типу, у яких за класифікацією ETDRS виявлена легка (14 хворих, 14 очей) і помірна (18хворих, 18 очей) стадії НПДР. Для дослідження Ти, іп vitro використовували аденозиндифосфат (АДФ), адреналін, ангіотензин-2 (Анг-2), фактор активації тромбоцитів (ФАТ) і колаген. Оцінку агрегації Ти проводили турбидиметричним методом на аналізаторі Chronolog (США). Результати. У пацієнтів з ДМП при помірній стадії НПДР виявлена більша реактивність Ти, до Анг-2, ФАТ і адреналіну, ніж при легкій стадії ( $><0,01)$. Даний феномен відбивав підвищення агрегації Ти, внаслідок порушень симпатоадреналової та ренін-ангіотензинової систем та зростання тязккості запалення. Гіперреактивність Ти до Анг-2 була причиною розвитку ДМН у хворих з ДМП при помірній стадії НПДР. Висновки. Патогенетичні чинники ЦД можуть провокувати проагрегантний статус Ти і тим самим викликати порушення мікроциркуляції в оболонках ока, що супроводжсується розвитком ДМП $і$ ДМН. Ключові слова: діабетична макулопатія; діабетичний макулярний набряк; непроліферативна діабетична ретинопатія; агрегація тромбоцитів
\end{abstract}

\section{Вступ}

Більшість існуючих методів дослідження діабетичної макулопатії (ДМП) та діабетичного макулярного набряку (ДМН) заснована на наявності морфологічних змін на очному дні [1]. Звичайно, краще виявляти зміни на ранніх біохімічних і фізіологічних етапах розвитку патології сітківки, що дозволило б відповідні індикатори використовувати для прогнозування ризику ДМН. У цьому контексті перспективним є дослідження проагрегантного стану тромбоцитів (Тц), який може ініціювати тромбози і геморагії судин сітківки, ішемію нейросенсорних клітин і глії, розвиток запалення і акумуляцію інтерстиціальної рідини [2].
Це, на нашу думку та засновуючись на даних літератури, обгрунтовано тим, що, по-перше, Тц мають рецептори до різних агоністів, що викликає зростання їх функціональної активності під впливом патогенетичних чинників цукрового діабету (ЦД), зокрема при активації ренін-ангіотензинової та симпатоадреналової систем (АТ -рецептори і $\alpha_{2}$-адренорецептори), розвитку запалення і ремоделювання міжклітинного матриксу (рецептори до фактора активації Тц - ФАТ і GPVIрецептори до колагену). Ключовими патогенетичними механізмами ДМН є: а) зростання проникності капілярів гематоретинального бар'єру (ГРБ) для білків плазми, що призводить до зростання інтерстиціального

(C) «Архів офтальмологіїУкраїни» / «Архив офтальмологии Украины» / «Archive Of Ukrainian Ophthalmology» («Arhìv oftal'mologiï Ukraïni»), 2018

() Видавець Заславський 0.Ю. / Издатель Заславский A.Ю. / Publisher Zaslavsky 0.Yu., 2018

Для кореспонденції: Могілевський Сергій Юрійович, доктор медичних наук, професор, Національна медична академія післядипломної освіти імені П.Л. Шупика, вул. Дорогожицька, 9, м. Київ, 04112, Україна; e-mail: redact@i.ua

For correspondence: S. Mogilevskyy, MD, PhD, Professor, Shupyk National Medical Academy of Postgraduate Education, Dorohozhytska st., 9, Kyiv, 04112, Ukraine; e-mail: redact@i.ua 
осмотичного тиску (онкотичний механізм); б) артеріальна гіпертензія, що провокує підвищення капілярного гідростатичного тиску (гідростатичний механізм) [3, 4]. По-друге, Тц безпосередньо впливають на морфофункціональний стан ендотелію капілярів: нещодавні дослідження C. Deppermann (2018) продемонстрували, що при запаленні Тц беруть участь у підтримці цілісності ГРБ завдяки експресії GPVI-рецепторів до колагену, CLEC-2, інтегрину $\alpha$ IIbß3 (GPIIb/IIIa), а також секреції біологічно активних речовин із $\alpha$ - та щільних гранул [5]. Однією із таких молекул може бути аденозиндифосфат (АДФ). Доведено, що ендотелій судин експресує пуринові рецептори $\mathrm{P} 2 \mathrm{Y}_{12}$; якщо заблокувати ці рецептори, то ендотеліальні клітини знижують експресію прозапальних молекул адгезії VCAM-1 (vascular cell adhesion molecule-1) та міграцію макрофагів у сітківку. Таким чином, регулюється ще один механізм утворення ДМН підвищення проникності судинної стінки [6]. По-третє, активовані Тц формують тромбоцитарно-лейкоцитарні агрегати в циркулюючій крові, що забезпечує адгезію лейкоцитів до ендотелію, також призводить до зростання проникності судинної стінки [7]. Крім того, Тц можуть регулювати патологічний ангіогенез завдяки формуванню проангіогенного фенотипу Тц, який характеризується зростанням продукції і секреції про- та антиангіогенних чинників [8]. Встановлено, що $\alpha$-гранули містять широкий спектр білків, які регулюють ангіогенез (VEGF, ендостатин, ангіостатин та ін.) [9].

Таким чином, можна сподіватися, що аналіз функціональної активності Тц при діабетичній ретинопатії (ДР) дозволить сформувати уявлення стосовно чинників, що можуть провокувати проагрегантний статус Тц та викликати порушення мікроциркуляції в оболонках ока і розвиток ДМП і ДМН. Для успішного рішення проблеми необхідно відповісти на ряд питань: чи розвиток ДМН обумовлений такими ж патогенетичними чинниками ЦД, які беруть участь в прогресуванні ДМП при непроліферативній ДР; реактивність Тц до якого з агоністів більшою мірою відображає їх участь в розвитку ДМН?

У літературі є повідомлення про вплив функціонального стану тромбоцитів на порушення мікроциркуляції сітківки хворих на ЦД 2-го типу [19].

Раніше нами також були опубліковані дані щодо функціонального стану Тц у хворих на ЦД 2-го типу і непроліферативною ДР [18, 20].

Мета дослідження: проаналізувати порушення агрегації Тц при ДМН та ДМП за умов непроліферативної діабетичної ретинопатії (НПДР) при ЦД 2-го типу.

\section{Матеріали та метоАи}

Дослідження носило проспективний характер i включало 32 хворих (32 ока) із ЦД 2-го типу, у яких за результатами клініко-інструментального обстеження та відповідно до класифікації ETDRS виявлена легка (14 хворих, 14 очей) і помірна (18 хворих, 18 очей) стадії непроліферативної ДР.

Усім хворим були виконані загальноприйняті офтальмологічні дослідження, що включали візометрію, статичну периметрію Humphrey, рефрактометрію, тонометрію, біомікроскопію, гоніоскопію, офтальмоскопію за допомогою асферичної лінзи Volk Super/ Field (NC USA) і контактної трьохдзеркальної лінзи Гольдмана. Всім хворим виконували спектрально-доменну оптичну когерентну томографію (ОCT) на приладі Optopoltechnology, SOCT, Copernicus REVO (протокол Retina3D, RetinaRaster) і ОСТ в режимі «Ангіо» (протокол RetinaAngio, wide 6 х 6 mm). Також виконували дослідження очного дна на фундус-камері з його фотографуванням в 7 стандартних полях відповідно до модифікованої ETDRS системою клінічних ознак AirlieHouse. Флуоресцентну ангіографію (ФАГ) виконували за показаннями (у разі підозри на приховану неоваскуляризацію, яка не була ідентифікована офтальмоскопічно, і по фотографіях очного дна, а також у разі невідповідності зорових функцій офтальмоскопічним змінам в макулярній області або за даними ОСТ).

Рівень тяжкості ДР встановлювали відповідно до Міжнародної клінічної шкали тяжкості діабетичної ретинопатії Американської академії офтальмології (2002 р.). Рівень тяжкості ДМП встановлювали відповідно до Міжнародної клінічної шкали тяжкості діабетичної макулопатії Американської академії офтальмології (2002 р.).

ДМП встановлювали при наявності специфічних діабетичних змін сітківки в макулярній області: мікроаневризм, геморагій, інтраретинальних мікросудинних аномалій, вітреоретинальної судинної проліферації. Наявність ішемічної форми ДМП встановлювали при розширенні судинної аваскулярної зони i/або наявності зон капілярної оклюзії в макулярній області за даними ангіо-ОСТ і/або ФАГ. ДМН встановлювали при збільшенні товщини сітківки більше значень нормативної бази даних по полях ETDRS програмного забезпечення спектрально-доменної ОСТ (зазначалося колірною шкалою, що підтверджувало збільшення товщини сітківки за межі норми - жовтим «р $<0,05 »$ або червоним «p $<0,01 »$ кольором). Збільшення товщини сітківки відзначали як без порушення архітектоніки, так і з їі порушенням (кістозні порожнини в нейроепітелії, відшарування нейроепітелію, гіперрефлективні включення на рівні нейроепітелію, відповідні твердому ексудату, порушення архітектоніки внутрішніх шарів сітківки, відповідні інтраретинальним крововиливам або ватному ексудату). Пацієнтів із ДМП при помірній непроліферативній ДР також було розбито на дві підгрупи: підгрупа А - 3 діагностованим ДМН $(\mathrm{n}=10)$ та підгрупа Б $(\mathrm{n}=8)-$ без ДМН. У хворих з ДМП та легкою стадією непроліферативної ДР ДМН визначений не був у жодному випадку.

Дослідження агрегації Тц (АТц) проводили на базі Науково-дослідного інституту експериментальної та клінічної медицини Національного медичного університету імені О.О. Богомольця. Тц виділяли шляхом центрифугування із цитратної периферичної крові пацієнтів і використовували для оцінки функціональної активності рецепторів. В дослідженні застосовували агоністи, що залучені у патогенез ЦД, зокрема: АДФ, який забезпечує автокринну стимуляцію Тц, накопичується в щільних гранулах і підтримує проагрегантний статус Тц; адреналін - гуморальний фактор, рівень якого зростає 
за умов стрес-реакції внаслідок активації симпатоадреналової системи; ангіотензин-2 (Анг-2) - гуморальний фактор, рівень якого зростає внаслідок активації ренінангіотензинової системи; ФАТ - паракринний медіатор, що забезпечує стимуляцію Тц, а також взаємодію лейкоцитів і Тц у реалізації запалення; колаген - системний чинник, що відбиває вплив концентрації розчиненого колагену в крові та/або експресії колагену міжклітинного матриксу на тромбоцитарну ланку гемостазу.

Агоністи (Sigma, США) використовували в ефективній концентрації $\left(\mathrm{EC}_{50}\right)$, яка викликала АТц на рівні $50 \pm 5 \%$. Для адреналіну вона становила $2,5 \pm 0,1$ мкМ, для колагену $-1,00 \pm 0,03$ мг/мл, для Анг- $-1,00 \pm 0,06$ мкМ, для ФАТ $-75,0 \pm 2,6$ мкМ і для АДФ - 2,50 \pm 0,05 мкМ. Оцінку агрегації Тц проводили турбодиметричним методом на аналізаторі Chronolog (США).

У всіх обстежених отримано інформовану згоду пацієнта на участь в дослідженні.

При проведенні аналізу використовували статистичний пакет Medcalc. Точкова оцінка величин, що підлягали аналізу, проводилася шляхом розрахунку середнього арифметичного $(\bar{X})$ та відповідної стандартної похибки (m) або медіани $\left(\mathrm{Me} ; \mathrm{Q}_{\mathrm{I}} ; \mathrm{Q}_{\mathrm{III}}\right)$. При аналізі міжгрупових розбіжностей застосовували критерій Стьюдента (у випадку нормального закону розподілу та кількісних характеристик), критерій Вілкоксона (у випадку відмінності закону розподілу від нормального та кількісних характеристик), метод кутового перетворення Фішера (у випадку порівняння частоти якісних ознак). У всіх випадках відмінність вважалася статистично значущою при рівні значущості $\mathrm{p}<0,05$.

\section{Результати та обговорення}

У пацієнтів з ДМП за умов помірної непроліферативні ДР мала місце гіперреактивність Тц стосовно чотирьох агоністів: колагену, адреналіну, Анг-2 і ФАТ (табл. 1). Причому порівняно з ДМП при легкій стадії непроліферативної ДР виявлена більша реактивність Тц до Анг-2 (на 21,2 \%; р < 0,001), ФАТ (на 19,0\%; $\mathrm{p}<0,001)$ і адреналіну (на 9,1\%; $<00,05)$. Реакція Тц на колаген відповідала діапазону гіперреактивності (57-74 \%) і була порівнянною в обох підгрупах.

Необхідно підкреслити, що при аналізі групової реактивності Тц у пацієнтів з ДМП при помірній стадії непроліферативної ДР провідним фактором індукції
АТц був адреналін, стосовно якого ефект Анг-2 був меншим на 8,3 \%, ФАТ - на 10,5 \%, колагену - на $11,8 \%$ і АДФ - на 32,1 \% ( $<<0,01$ для всіх порівнянь). Таким чином, у хворих з ДМП при помірній непроліферативній ДР мав місце гіперадренореактивний тромбогенний фенотип. В даному фенотипі реакція Тц на колаген і ФАТ була на 14,7 і 13,3 \% відповідно менше, ніж на Анг-2 (p < 0,001); а реакція Тц на АДФ була на 14,5\% менше, ніж така на ФАТ ( $<<0,001)$.

Показано, що у хворих з ДМП при легкій та помірній стадіях непроліферативної ДР виявлена загальна риса - гіперреактивність Тц на колаген на тлі нормореактивності до АДФ; а отже, ремоделювання міжклітинного матриксу сполучної тканини є неспецифічним механізмом на ранніх стадіях ДМП при розвитку ДР. Реакція Тц на колаген може бути інформативним індикатором їх функціонального стану при ДМП. До особливостей реактивності Тц хворих з ДМП при помірній стадії непроліферативної ДР можна було віднести зростаючий вплив адреналіну, Анг-2 і ФАТ (p < 0,01). Даний феномен відбивав підвищення стимуляції $\alpha 2-$ адрено-, АТ1- і ФАТ-рецепторів Тц при прогресуванні порушень в симпатоадреналовій і ренін-ангіотензиновій системах та зростанні тяжкості запалення. За цих умов відтворювався новий якісний рівень гіперреактивності Тц, наслідком чого може бути зміна спектра секретованих речовин, що забезпечувало зростання морфологічних змін на очному дні (збільшення кількості мікроаневризм і мікрогеморагій, появу ватного ексудату, інтраретинальних мікросудинних аномалій і сегментарного розширення вен сітківки).

Таким чином, вираженість активації регуляторних систем і запальної реакції можуть розглядатися як фактори ризику прогресування ДМП при переході від легкої до помірної стадії непроліферативної ДР, а функціональна активність $\alpha 2$-адренорецепторів, АТ1-рецепторів і ФАТ-рецепторів Тц може бути інформативним індикатором для прогнозування ризику прогресування ДМП.

До теперішнього часу невідомо, чи відрізняється функціональна активність Тц при ДМП за умов розвитку ДМН. Чому при тій же самій стадії ДМП у одних хворих виникає ДМН, а у других він відсутній? Відповідь на ці питання необхідна у зв'язку з пошуком інформативних індикаторів для прогнозування ризику розвитку ДМН. В даному контексті мало сенс перерозподілити пацієнтів із ДМП при помірній стадії не-

Таблиця 1. Індукована АТц (\%) у хворих з ДМП при непроліферативній ДР

\begin{tabular}{|c|c|c|c|c|}
\hline \multirow{2}{*}{ Індуктор АТц } & \multicolumn{2}{|c|}{$\begin{array}{c}\text { Легка стадія ( } n=14) \\
\text { (II стадія згідно з ETDRS) }\end{array}$} & \multicolumn{2}{|c|}{$\begin{array}{c}\text { Помірна стадія (n=18) } \\
\text { (III стадія згідно з ETDRS) }\end{array}$} \\
\hline & Me & $Q_{1} \div Q_{I I I}$ & Me & $Q_{1} \div Q_{1 I I}$ \\
\hline Адреналін (2,5 мкM) & 71,5 & $70,0-74,0$ & $78,0^{*}$ & $76,0-79,0$ \\
\hline Анг-2 (1,0 мкM) & 59,0 & $57,0-60,0$ & $71,5^{\star *}$ & $69,0-74,0$ \\
\hline Колаген (1,0 мг/мл) & 67,5 & $63,0-70,0$ & 61,0 & $57,0-74,0$ \\
\hline ФАТ (75,0 мкM) & 52,0 & $50,0-54,0$ & $62,0^{* *}$ & $60,0-64,0$ \\
\hline АДФ (2,5 мкМ) & 50,5 & $49,0-52,0$ & $53,0^{*}$ & $52,0-55,0$ \\
\hline
\end{tabular}

Примітки: * - вірогідність розбіжностей АТц при помірній стадії непроліферативної ДР стосовно легкої стадії на рівні $p<0,01$; ** - на рівні $p<0,001$. 
проліферативної ДР на дві підгрупи: підгрупу А - 10 $(55,6 \%)$ хворих, у яких був виявлений ДМН (товщина сітківки в центральній зоні > 300 мкм), та підгрупу Б $8(44,4 \%)$ хворих, у яких ДМН діагностовано не було. Порівняння функціональної активності Тц в межах однієї стадії з наявністю ДМН і без ДМН дозволило відповісти на ключове питання: які фактори патогенезу ДМП при помірній непроліферативній ДР впливали на розвиток ДМН, тобто були специфічними для зростання проникності ГРБ і акумуляції інтерстиціальної рідини в макулі сітківки?

Проведене дослідження показало, що в підгрупі А зберігалася гіперреактивність Тц стосовно чотирьох агоністів: адреналіну, Анг-2, ФАТ і колагену (табл. 2).

Аналіз адренореактивності Тц свідчив, що у цих пацієнтів мала місце гіперреактивність $\alpha_{2}-$ адренорецепторів. Реакція Тц на адреналін перевищувала таку на Анг-2 на 5,8 \% ( $=0,007)$, ФАТ - на $21,9 \%(\mathrm{p}<0,001)$, колагену - на 33,7 \% (p < 0,001), АДФ - на 42,9\% (p <0,001). Таким чином, кластер активності рецепторів мав наступний вигляд: активність $\alpha_{2}$-адренорецептора $>\mathrm{AT}_{1}$-рецептора $>$ ФАТ-рецептора $>$ GPVI-рецептора $>$ пуринових рецепторів.

У хворих підгрупи Б також виявлена гіперреактивність $\alpha_{2}$-адренорецепторів. Реакція Тц на адреналін перевищувала таку на колаген на $3,8 \%$ ( Анг-2 - на 13,3 \% (p < 0,001), ФАТ - на 29,3\% ( $<<0,001)$, колагену - на 33,7\% (p <0,001), АДФ на 47,4 \% (p <0,001). Отже, кластер активності рецепторів Тц в підгрупі Б мав інший вигляд: активність $\alpha_{2}-$ адренорецептора > GPVI-рецептора $>\mathrm{AT}_{1}$-рецептора $>$ ФАТ-рецептора $>$ пуринових рецепторів.

У хворих з ДМП при помірній стадії непроліферативної ДР при наявності чи відсутності ДМН відрізнялася реакція Тц на колаген і Анг-2: при наявності ДМН реакція Тц на Анг-2 перевищувала таку в підгрупі пацієнтів без ДМН на 5,1 \% (p < 0,05), тоді як при відсутності ДМН реактивність Тц до колагену перевищувала таку на 31,3 \% ( $<$ 0,001) стосовно підгрупи хворих без ДМН. Реакція Тц до адреналіну, ФАТ і АДФ статистично значуще не відрізнялася ( $\mathrm{p}>0,05)$.

Таким чином, у пацієнтів з ДМП при помірній стадії непроліферативної ДР був представлений гіперадренореактивний фенотип Тц, який характеризувався двома кластерами функціонального стану рецепторів, що відбивало різний ступінь індукуючого впливу Анг-2 і колагену на Тц залежно від наявності ДМН. Причому ефекти цих патогенетичних факторів полярні: при наявності ДМН реєструвалася більш виражена реакція Тц на Анг-2, що відбивало суттєве зростання активності ренін-ангіотензинової системи (внаслідок чого підвищувалася сенситивність АТ -рецепторів Тц), тоді як стан міжклітинного матриксу сітківки лишався стабільним (нормореактивність GPVI-рецепторів чи їх невелика гіперреактивність у частини хворих).

Протилежний ефект демонстрував кластер при відсутності ДМН - зростала реакція Тц на колаген (підвищувалася сенситивність GPVI-рецепторів Тц), тоді як активність ренін-ангіотензинової системи зменшувалася (знижувалася гіперреактивність $\mathrm{AT}_{1}$-рецепторів Тц). Отже, з трьох встановлених факторів ризику прогресування ДМП при непроліферативній ДР (активація симпатоадреналової, ренін-ангіотензинової систем і запалення) саме гіперреактивність Тц до Анг-2 могла бути причиною розвитку ДМН.

Механізми цього ефекту можуть бути різними. Підвищення рівня Анг-2 через стимуляцію $\mathrm{AT}_{1}$-рецепторів призводить до зростання експресії VEGF, який пошкоджує ГРБ [10], та накопичення міжклітинного матриксу, що призводить до розвитку фіброзу [11]. Причому гіперглікемія стимулює експресію гена ангіотензиногену через шлях обміну гексозаміну і, таким чином, збільшує синтез Анг-2 [12]. Блокада $\mathrm{AT}_{1}$-рецепторів на ендотеліальних клітинах і перицитах судин забезпечує цитопротекторні ефекти. Експериментальне дослідження [13] показало, що інгібування ренін-ангіотензинової системи послаблювало підвищену судинну проникність сітківки при ЦД, що супроводжувалося відновленням тісних зв'язків міжклітинних білків в стінці судин. Результати останніх клінічних випробувань [14] свідчили про роль блокаторів ренін-ангіотензинової системи (інгібіторів АПФ і блокаторів рецепторів Анг-2) та фенофібрату в зниженні прогресії та/або індукції регресії від помірної до легкої стадії непроліферативної ДР.

Інгібітори АПФ ефективні для затримки прогресування ДР, але невідомо, чи є виправданим їх використання у хворих з ДМН. Зокрема, [15] не виявили ніякого сприятливого ефекту інгібітору АПФ у хворих із діабетичною макулярної ішемією. Нові сподівання надали дослідження [16], які були проведені на трансгенних щурах dTGR, в сітківці яких мала місце підви-

Таблиця 2. Індукована АТц (\%) у хворих з ДМП при помірній стадії непроліферативної ДР за наявністю ДМН (підгрупа А) та без нього (підгрупа Б)

\begin{tabular}{|c|c|c|c|c|}
\hline \multirow{2}{*}{ Індуктор АТц } & \multicolumn{2}{|c|}{ Підгрупа A (n = 10) } & \multicolumn{2}{|c|}{ Підгрупа Б (n = 8) } \\
\hline & $\bar{X} \pm$ SD & Min - Max & $\bar{X} \pm \mathrm{SD}$ & Min - Max \\
\hline Адреналін (2,5 мкM) & $76,9 \pm 0,9$ & $71,0-81,0$ & $78,4 \pm 0,7$ & $76,7-81,0$ \\
\hline Колаген (1,0 мг/мл) & $57,5 \pm 0,7^{\star \star}$ & $55,0-62,0$ & $75,5 \pm 0,9$ & $73,0-79,0$ \\
\hline Анг-2 (1,0 мкM) & $72,7 \pm 1,0^{\star}$ & $65,0-77,0$ & $69,2 \pm 1,0$ & $65,0-74,0$ \\
\hline ФАТ (75,0 мкМ) & $63,1 \pm 1,0$ & $57,0-67,0$ & $61,1 \pm 0,8$ & $58,0-65,0$ \\
\hline АДФ (2,5 мкМ) & $53,8 \pm 1,2$ & $50,0-63,0$ & $53,2 \pm 0,7$ & $50,0-56,0$ \\
\hline
\end{tabular}

Примітки: * — вірогідність розбіжностей АТц в підгрупі А стосовно такої в підгрупі Б на рівні $p<0,05$; ** на рівні $p<0,001$. 
щена експресія ангіотензиногену та реніну. За цих умов виявлялась дегенерація гангліозних клітин сітківки.

V.M. Milenkovic et al. (2010) [17] встановили, що системне введення інгібітору АПФ підвищувало експресію реніну в пігментних клітинах сітківки. Даний факт підтвердив гіпотезу, що локальна експресія реніну в клітинах ГРБ знаходиться під контролем ренінангіотензинової системи організму. У світлі наведених фактів і отриманих у даному дослідженні результатів інгібітори АПФ можуть мати терапевтичний потенціал при лікуванні ДМП і ДМН.

\section{Висновки}

1. Патогенетичні чинники ЦД можуть провокувати проагрегантний статус Тц та тим самим викликати порушення мікроциркуляції в оболонках ока, що супроводжується розвитком ДМП і ДМН при непроліферативній ДР. Аналіз функціональної активності Тц дозволив оцінити вплив патогенетичних факторів ЦД на прогресування ДМП і розвиток ДМН.

2. У хворих з ДМП при легкій і помірній стадіях непроліферативної ДР виявлена загальна риса - гіперреактивність Тц на колаген, а отже, ремоделювання міжклітинного матриксу сполучної тканини є неспецифічним механізмом розвитку ДМП на ранніх стадіях. До особливостей реактивності Тц хворих із ДМП при помірній стадії непроліферативної ДР відносився зростаючий вплив адреналіну, Анг-2 і ФАТ, що відбивало прогресування порушень в симпатоадреналовій і ренін-ангіотензиновій системах, та вираженість запалення, наслідком чого був новий функціональний стан Тц (кластер), який обумовлював відповідні морфологічні зміни на очному дні.

3. Вираженість активації симпатоадреналової і ренін-ангіотензинової системи та запальної реакції можуть розглядатися як чинники ризику прогресування ДМП при непроліферативній ДР, а функціональна активність $\alpha_{2}$-адренорецепторів, АТ рецепторів Тц можуть бути інформативними індикаторами прогнозування ДМП. Гіперреактивність Тц до Анг-2 могла бути причиною розвитку ДМН.

Конфлікт інтересів. Автори заявляють про відсутність конфлікту інтересів при підготовці даної статті.

\section{Список мітератури}

1. Macular integrity assessment to determine the association between macular microstructure and functional parameters in diabetic macular edema / J.W. Wang, C.H. Jie, Y.J. Tao [et al.] // Int. J. Ophthalmol. - 2018. - Vol. 11(7). - P. 1185-1191.

2. Diabetic retinopathy: Breaking the barrier / R.S. Eshaq, A.M.Z. Aldalati, J.S. Alexander, N.R. Harris // Pathophysiology. 2017. - Vol. 24(4). - P. 229-241.

3. Shilpi K. A study of platelet indices in type 2 diabetes mellitus patients / K. Shilpi, R.M. Potekar // Indian J. Hematol. Blood Transfus. - 2018. - Vol. 34(1). - P. 115-120.

4. Cunha-VazJ. The blood-retinal barrier in the management of retinal disease: EURETINA Award Lecture /J. Cunha-Vaz//Ophthalmologica. - 2017. - Vol. 237(1). - P. 1-10.
5. Deppermann C. Platelets and vascular integrity / C. Deppermann // Platelets. - 2018. - Vol. 15. - P. 1-7.

6. Ticagrelor, a P2Y12 antagonist, attenuates vasculardysfunction and inhibits atherogenesis in apolipoprotein-E-deficient mice / B. Ganbaatar, D. Fukuda, H.M. Salim [et al.] // Atherosclerosis. 2018. - Vol. 275. - P. 124-132.

7. Blum A. Vascular responsiveness in type 2 diabetes mellitus (T2DM) / A. Blum, D. Socea, R. Sirchan // QJM. - 2016. Vol. 109(12). - P. 791-796.

8. Temporal and pharmacological characterization of angiostatin release and generation by human platelets: implications for endothelial cell migration / A. Radziwon-Balicka, C.M. de la Rosa, B. Zielnik [et al.]// PLOS ONE. - 2013. - Vol. 8(3). - e59281.

9. Angiogenesis is regulated by a novel mechanism: pro- and antiangiogenic proteins are organized into separate platelet alpha granules and differentially released / J.E. Italiano, J.L. Richardson, S. PatelHett [et al.] // Blood. - 2008. - Vol. 111(3). - P. 1227-1233.

10. Lally D.R. Vascular endothelial growth factor and diabetic macular edema / D.R. Lally, C.P. Shah, J.S. Heier // Surv. Ophthalmol. - 2016. - Vol. 61(6). - P. 759-768.

11. Changes in vitreous VEGF, bFGF and fibrosis in proliferative diabetic retinopathy after intravitreal bevacizumab /J.K. Li, F. Wei, X.H. Jin [et al.]// Int. J. Ophthalmol. - 2015. - Vol. 8(6). - P. 1202-1206.

12. Constitutive activation of the renin-angiotensin system reduces visceral fat and improves glucose tolerance in mice / G.A. Favre, P. Lebrun, P. Lopez [et al.] // J. Renin Angiotensin Aldosterone Syst. - 2014. - Vol. 15(4). - P. 396-409.

13. Blockade of angiotensin II attenuates VEGF-mediated blood-retinal barrier breakdown in diabetic retinopathy / J.H. Kim, J.H. Kim, Y.S. Yu [et al.]//J. Cereb. Blood Flow. Metab. - 2009. Vol. 29(3). - P. 621-628.

14. Porta M. The changing role of the endocrinologist in the care of patients with diabetic retinopathy / M. Porta, A.V. Taulaigo // Endocrine. - 2014. - Vol. 46(2). - P. 199-208.

15. Systemic oxygen therapy versus oral enalapril for treatment of diabetic macular ischemia: a randomized controlled trial / F. Sharifipour, M. Razzaghi, A. Ramezani [et al.] // Int. Ophthalmol. 2016. - Vol. 36(2). - P. 225-235.

16. Hypertensive retinopathy in a transgenic angiotensin-based model / N. Reichhart, N. Mezouar, V. Domenga-Denier [et al.] // Clin. Sci. (Lond.). - 2016. - Vol. 130(13). - P. 1075-1088.

17. Regulation of the renin expression in the retinal pigment epithelium by systemic stimuli / V.M. Milenkovic, M. Brockmann, C. Meyer [et al.] // Am. J. Physiol. Renal. Physiol. - 2010. Vol. 299(2). - F396-403.

18. Hudz A.S. Functional status of platelets in type 2 diabetes patients showing no diabetic fundus changes / A.S. Hudz, S.Iu. Mogilevskyy, M.L. Maksymtsiv // J. ophthalmol. (Ukraine). - 2017. Vol. 1. - P. 20-24.

19. Гудзь А.С. Функціональний стан тромбоцитів і порушення мікроциркуляції сітківки у пацієнтів, хворих на цукровий діабет 2-го типу / А.С. Гудзь, М.Л. Максимців // Архів офтальмології України. - 2017. - Т. 2(8). - С. 27-32.

20. Протромбогенний фенотип тромбоцитів у пацієнтів із непроліферативною діабетичною ретинопатією / А.С. Гудзь, М.Л. Максимиів, С.В. Зябліцев, С.Ю. Могілевський// Міжннародний ендокринологічний журнал. - 2018. - Т. 14, № 2. - C. 143-147. DOI: http://dx.doi.org/10.22141/2224-0721.14.2.2018.130558.

Отримано 30.09.2018 


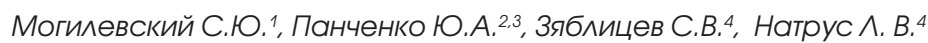

${ }^{1}$ Национальная меАицинская акаАемия посляАипломного образования имени П.А. Шупика МОЗ Украины,

г. Киев, Украина

2 Киевская городская клиническая офтальмологическая больница "Центр микрохирургии глаза», г. Киев, Украина

${ }^{3}$ МеАИцинсКИй центр "ААЗЕР ПАюС", г. Аьвов, УКраина

${ }^{4}$ Національный медицинский университет имени А.А. Богомольца МОЗ Украины, г. Киев, Украина

\section{Нарушение агрегации тромбоцитов как фактор развития Аиабетической макулопатии и Аиабетического макулярного отека у больных с непролиферативной Аиабетической ретинопатией при сахарном Аиабете 2-го типа}

Резюме. Актуальность. Анализ современных данных позволяет выдвинуть предположение, что патогенетические факторы сахарного диабета (СД) могут провоцировать проагрегантный статус тромбоцитов (Тц) и вызывать нарушение микроциркуляции в оболочках глаза и развитие диабетической макулопатии (ДМП) и диабетического макулярного отека (ДМО). Цель исследования - проанализировать нарушения агрегации Тц при ДМП и ДМО в условиях непролиферативной диабетической ретинопатии (НПДР) при СД 2-го типа. Материалы и методы. Исследование включало 32 больных (32 глаза) с СД 2-го типа, у которых по классификации ETDRS обнаружена легкая (14 больных, 14 глаз) и умеренная (18 больных, 18 глаз) стадии НПДР. Для исследования Тц in vitro использовали аденозиндифосфат (АДФ), адреналин, ангиотензин-2 (Анг-2), фактор активации тромбоцитов (ФАТ) и коллаген. Оценку агрегации
Тц проводили турбидиметрическим методом на анализатоpe Chronolog (США). Результаты. У пациентов с ДМП при умеренной стадии НПДР обнаружена большая реактивность Тц в ответ на Анг-2, ФАТ и адреналин, чем при легкой стадии $(\mathrm{p}<0,01)$. Данный феномен отражал повышение агрегации Тц вследствие нарушений симпатоадреналовой и ренин-ангиотензиновой систем и усиление воспаления. Гиперреактивность Тц к Анг-2 была причиной развития ДМО у больных с ДМП при умеренной стадии НПДР. Bыводы. Патогенетические факторы СД могут провоцировать проагрегантный статус Тц, тем самым вызывать нарушения микроциркуляции в оболочках глаза, сопровождающиеся развитием ДМП и ДМО.

Ключевые слова: диабетическая макулопатия; диабетический макулярный отек; непролиферативная диабетическая ретинопатия; агрегация тромбоцитов

S. Yu. Mogilevskyy', Yu. O. Panchenko2,3, S. V. Ziablitsev', L. V. Natrus ${ }^{4}$

${ }_{1}^{1}$ Shupyk National Medical Academy of Postgraduate Education of the Ministry of Health of Ukraine, Kyiv, Ukraine

${ }^{2}$ Kyiv Clinical Ophthalmology Hospital Eye Microsurgery Center, Kyiv, Ukraine

${ }^{3}$ Medical Center "Lazer Plus", Lviv, Ukraine

${ }^{4}$ Bogomolets National Medical University of the Ministry of Health of Ukraine, Kyiv, Ukraine

\section{Disturbed platelet aggregation as a factor of diabetic maculopathy and diabetic macular edema in patients with nonproliferative diabetic retinopathy in type 2 diabetes mellitus}

Abstract. Background. The analysis of current data makes it possible to suggest that the pathogenetic factors of diabetes mellitus (DM) can provoke the proaggregant status of platelets and cause microcirculatory disturbances in the eye membranes and the development of diabetic maculopathy (DMP) and diabetic macular edema (DMA). The purpose of the study is to analyze the disturbed platelet aggregation in DMA and DMP in nonproliferative diabetic retinopathy (NPDR) with type $2 \mathrm{DM}$. Materials and methods. The study included 32 patients ( 32 eyes) with type $2 \mathrm{DM}$, in whom mild (14 patients, 14 eyes) and moderate (18 patients, 18 eyes) stages of NPDR were detected according to the Early Treatment Diabetic Retinopathy Study classification. Adenosine diphosphate, adrenaline, angiotensin-2 (Ang-2), platelet-activating factor (PAF), and collagen were used to study platelets in vitro. Platelet aggregation was evaluated using turbidimetric method on Chronolog analyzer (USA). Results. Patients with DMP in moderate NPDR showed greater reactivity of platelets to Ang-2, PAF, and adrenaline than with the mild stage $(p<0.01)$. This phenomenon reflected an increase in platelet aggregation due to violations of sympathoadrenal and renin-angiotensin systems and an increase in the severity of inflammation. Platelet hyperreactivity to Ang-2 was the cause of DMA in patients with DMP at moderate stage of NPDR. Conclusions. Pathogenetic factors of DM can provoke proaggregant status of platelets and, thus, cause microcirculatory disturbances in the eye membranes, which is accompanied by the development of DMP and DMA.

Keywords: diabetic maculopathy; diabetic macular edema; nonproliferative diabetic retinopathy; platelet aggregation 